UDC 338:614

JEL Classification: I14, I12, P46

http://doi.org/10.21272/mmi.2019.3-12

Irena Antosova,

Mendel University in Brno, Czech Republic

Nad'a Hazuchova,

Ph.D., Mendel University in Brno, Czech Republic

Jana Stavkova,

CSc., Professor, Mendel University in Brno, Czech Republic

\title{
MARKET SEGMENTATION IN HEALTHCARE
}

Abstract. The share of healthcare expenditure in the first income decile in their income is higher in comparison with other deciles, however, their expenditure is the lowest. The main purpose of the research is to show the availability of healthcare in different income groups of households. Literature sources indicate that some specific household social classes face problems with access to healthcare because of low income. Firstly, public healthcare expenditure is evaluated. The low share of research and development expenditure in healthcare is alarming. Investigation continues in the accessibility of healthcare and medicines in households. The paper reveals segments of endangered lowincome households with insufficient healthcare that decrease their living standard. The main data source for conducted analyses of household situations is primary data from Household Budget Survey and primary data from EU-Statistics on Income and Living Conditions survey in four years 2007, 2010, 2014 and 2016 in the Czech Republic. The paper presents the results of an analysis of households which showed that first low-income decile has the lowest healthcare payments in absolute expression but the relative number of healthcare expenditure confirms that low-income households spend the most of their income on healthcare in the comparison with other households. The first income decile is mainly composed of old-age pensioners and unemployed consumers. The structure of household healthcare expenditure according to expenditure categories shows that all consumers pay the most for non-prescription drugs followed by prescription drugs, orthopaedic and therapeutic aids, ambulatory dental care and ambulatory medical care. The research confirms that specific groups of households cannot afford appropriate healthcare. The constructed Health Poverty Index expresses that low-income households would need their income to be higher by at least $4.36 \%$ to be able to afford average healthcare expenditure and appropriate healthcare.

Keywords: consumer behaviour, health, health category, health expenditure, income situation.

Introduction. Health is one of the most precious human values. This fact is crucial when determining priorities and satisfying one's needs, i.e. when deciding about the structure of one's expenditure. Expenditure to ensuring healthcare, a healthy lifestyle, access to information about health and diseases, sufficient over-the-counter drugs and food supplements are all facts which the consumer considers when deciding about the expenditure for individual groups of goods and services, particularly for services and products contributing to one's health. The availability and ensuring of basic health care in required quality is a key determinant of country health policy and is one of the core objectives of OECD countries $(O E C D$, 2019, WHO, 2019).

Awareness of the unique nature of products and services for the health of the individual could be exploited by the product and service providers, i.e. the economic aspect of providers may outweigh all other aspects. The pricing and reimbursement of pharmaceuticals for maintaining health must be the subject of interest of the entire society stressing that health concerns all income and social groups of society. The pricing and reimbursement of pharmaceuticals is a significant aspect above all of the drugs that are reimbursed from public health insurance. Here pricing is regulated and upper limits are fixed of prices of the manufacturer and scope of the business mark-up of the distributor and pharmacy. Prescription drugs have a fixed amount of reimbursement of pharmaceuticals and the patient either does not pay any amount or only pays the difference between the retail price and the payment, i.e. the additional payment (Olecich.cz, 2017). Over-the-counter drugs are pharmaceuticals that are not reimbursed from

Cite as: Antosova, I., Hazuchova, N., Stakova, J. (2019). Market Segmentation in Healthcare. Marketing and Management of Innovations, 3, 151-166. http://doi.org/10.21272/mmi.2019.3-12 
health insurance and the patient pays their full price from his own money. The price of over-the-counter drugs is in the full competence of pharmaceutical companies, distributors and pharmacies. So the rules for the price of non-reimbursed pharmaceuticals does not in any way differ from determining the price of any other products such as food, cosmetics or other consumer goods (Olecich.cz, 2017). The prices of over-the-counter pharmaceuticals do not have a regulated manufacturer's price or business mark-up. The only regulation is just the competition between pharmaceutical companies, distributors and pharmacies. The retail price consists of the manufacturer's price, the business mark-up of the distributor and pharmacy and VAT.

Another crucial factor for the availability of health products is the amount of money that the consumer has at his disposal, whether and what part he can spend on these healthcare services and products. There are several other factors that affect consumers such as smoking and consumption of alcoholic beverages, overweight and obesity, consumption of fruit and vegetables, physical activity and many others which, among other things, closely relate to the consumer behaviour of the public and its decision-making concerning the satisfaction of needs.

The aim of the article is to show the availability of drugs, pharmaceuticals and healthcare services based on information about household healthcare expenditure (drug expenditure, over-the-counter pharmaceuticals and healthcare services) and information about a household's income situation. The subject of interest of this article is above all the low-income group of people and selected social groups with regard to satisfying needs according to individual categories of healthcare expenses. Propose an indicator for the quantitative expression of this relationship which will capture the need for the increase of income to achieve satisfactory healthcare.

Our paper is structured as follows. Firstly, we describe the issue concerning consumer behaviour in the healthcare area and we add current studies about this topic in the literature review. Secondary, we show used primary data and the methodology of the research. Results are explained in the next chapter. The last part of the paper is the conclusion of our study.

Literature Review. Consumer behaviour concerning the area of healthcare differs from other areas above all because this is a question of "life and death" therefore emotion influences decision-making to a far greater extent (Cazacu, 2015). Another significant difference is that the products and services are provided to consumers through a third party which most often is a doctor (Radulescu et al., 2012). So consumers do not make their own decisions, these are made by a doctor (Thomas, 2005). A good state of health is the determining factor for the quality of life. The state of health is affected by genetic and environmental factors, socio-economic and cultural conditions, it contributes to social assertion and general wellbeing. Most people are of the opinion that access to and quality of healthcare at an affordable price is one of the basic human needs and as such needs to be provided. Callander et al. (2019) show in his study that household healthcare expenditure affects the living standard of households and also points out that the country's healthcare systems are not perfect and cannot ensure drugs, health products and services for households living in poverty.

Many indicators of household income situation, income inequality, income poverty thresholds, material deprivation, their development and their long-term use make it necessary to compliment them further by comparing the ability to make ends meet, namely, to pay for usual necessary expenses (Bradbury et al., 2001; Rittakalio, Bradshaw, 2005; Atkinson et al., 2007; Guio, Museux, 2006).

Opinions differ as to whether income is the decisive variable that determines how much a household invests in health. Peacock et al. (1999) are of the opinion that no obstacles have been shown for access to healthcare. Khan and UI Husnain (2019) show that health care expenditure and income are cointegrated. Health care has been found a necessity good in Asian countries in the long run. The healthcare inequality based on the income situation of households occurs in many countries and lowincome households could face health problems (Wang et al., 2016; Mtei et al., 2015). Lenhart (2019) 
examined the effect of income on health and found that income improves the likelihood of affected heads of households reporting to be in excellent or very good health by 6.9 to 8.9 percentage points. Permanent income shocks affect health and lead to increases in mortality and risky health behaviour (Adda et al., 2009). Household healthcare expenditure, especially expenditures for medicines, pose a substantial financial burden to many households, particularly those with low incomes. Policies should minimize the cost burden of prescription medicines, particularly for low-income working households (Kemp et al., 2013).

Knaul et al. (2012) state that low-income households are exposed to higher healthcare expenditure. Chaupain-Guillot and Guillot (2015) show in their study that $24.9 \%$ of European households are unable to meet their medical care needs because of financial reasons and $50.6 \%$ of European households cannot afford dental care because of the same reason. Statistika\&My (2013) list healthcare expenditure by category. The use of over-the-counter drugs in a certain part of the population is becoming a substantial part of healthcare. The share is increasing of households that are burdened by healthcare expenditure (Zamazalova, 2009), and the same trend is recorded by most EU countries (Atanasova et al., 2015). This is the active approach of the individual and attempts to address his own health problems. He uses overthe-counter pharmaceuticals, food supplements or health products. If a patient lacks information about the use of over-the-counter pharmaceuticals this could result in a negative impact on his health (Metys and Balog, 2006).

In view of the unique nature of human healthcare and the importance of this care by the state, the European Commission (2019) created, for the purpose of monitoring, assessing and comparing this care in individual EU countries, a group of indicators which can be used to rate the availability and quality of care. The first group of indicators consists of the European Core Health Indicator (ECHI). These indicators express the demographic and socio-economic situation, health habits, state of health, healthcare services and healthcare support. A further indicator is the Healthy Life Years indicator which provides estimated life expectancy without health problems in people of a certain age.

Consumer behaviour depends on many factors. Demographic factors, such as age or gender, are usually crucial in all areas (Mokrysz, 2016). Chaupain-Guillot and Guillot (2015) proved that demographic and socio-economics factors such as gender, age or education affect consumer's health as well as income decile that a household belongs to. On the other hand, Yao et al. (2019) show that the education quantity has no significant effect on healthcare expenditure, while the education quality has a positive and significant effect. WHO (2019) also lists the factors significant for health that are publicly available for individual EU countries and can be used at any time: income and social position, education, environment and work safety, genetics, social support groups, healthcare services and gender position. Age is among other demographic factors very important determinant of health expenditure. Especially the elderly need to use hospital services more frequently and also medical expenditure is increasing in the group of elderly (Fukawa, 2017). Differences in healthcare expenditure are also noticeable in a categorization according to socio-economic status based on household income situation. Because of this it is necessary to increase the depth of social insurance coverage by expanding the basic benefit package (Kavosi et al., 2012).

Health is a component of human infrastructure and is influenced by public policies and governments (Globerman and Shapiro, 2002). Public policies also have an impact on healthcare innovations that positively affect the efficiency of the healthcare sector (Gadowska and Rozycka, 2016). The existence of a long-run causal relationship between GDP and health care expenditures has been proved in a group of Latin American countries and in OECD countries. However, healthcare is a necessity rather than a luxury in these countries (Rodriguez, Nieves Valdez, 2019). Another important fact on the level of states is that the influence of Foreign Direct Investments on public health expenditure and on the total health expenditure was found (Giammanco, Gitto, 2019). The correlation between health care expenditure, gross domestic product (GDP) and population over 65 years (the elderly) is a key question for health economics and demographic impact. The elderly positively affects health care expenditure per capita. State policies 
should aim at improving the access of people to health care services based on public health care expenditures (Pascual-Saez et al., 2017). Liu et al. (2016) draw attention to vulnerable groups of populations such as pensioners, who need to be taken into account during the development of health policies.

Methodology and research methods. The main source of data for the article is the Household Budget Survey (HBS) primary data which is a survey that monitors household management and provides information about the expenditure and consumption structure of households. The Household Budget Survey (HBS) is a source of information about household consumption expenditure based on their income, household structure, economic activity and other attributes. The Household Budget Survey looks at the segmentation according to the Individual Consumption Classification which was created as part of the transformation of the classification system as the Czech version of the international COICOP standard to provide an international comparison of statistical indicators and is binding for all statistical findings (CZSO ${ }^{1}$, 2019).

The Classification of individual consumption by purpose (COICOP) was developed by the United Nations Statistics Division for classifying and analysing household consumption expenditure and accepted by the European Union as a uniform methodology for a survey of household expenses in the European area. This classification includes 12 areas of consumption expenditure: food and non-alcoholic beverages; alcoholic beverages and tobacco; clothing and footwear; housing, water, energy, fuel; home furnishings and household amenities; healthcare; transport; post office and telecommunications; recreation, culture and sport (Eurostat $\left.{ }^{1}, 2019\right)$.

Households are selected for the HBS by intentional quota sampling according to several quota signs. The basic selection sign is a group of households, based on economic activity and position at work of the person at the head of the household, among the further quota signs are the net cash income of the household, composition of the household according to the number of children and adults, size of the municipality and type of house $\left(\mathrm{CZSO}^{1}, 2019\right)$. An overview of the number of households involved in the HBS in the monitored years is shown in the following table (Table 1). Years were selected when there was a change in the economic development in society.

Table 1. Number of households in the HBS

\begin{tabular}{|c|c|c|c|c|}
\hline & 2007 & 2010 & 2014 & 2016 \\
\hline Number of households & 2961 & 2933 & 2888 & 1583 \\
\hline
\end{tabular}

Source: HBS data.

Apart from HBS data, primary data from EU-SILC (European Union Statistics on Income and Living Conditions) survey are also used. An additional source of data is secondary data where the source is Eurostat and the Czech Statistical Office, particularly for determining macro-economic data on public expenditure for healthcare in the Czech Republic and its structure.

The main attention in this study is devoted to monthly consumer expenditure in healthcare per household and the share of healthcare expenditure in net disposable household income. Total household expenditure spent on healthcare means the total individual expenditure categories in healthcare for which the household spent a specific amount in the given month. Descriptive statistics are used in these analyses. The Chi-squared test is used to check the cogency of the difference between income risk groups and all households in total.

In the article, after the analyses the Health Poverty Index $I_{H P}$ is constructed which shows how much money income risk households lack to be able to spend on the healthcare of the required standard. The nature of the Health Poverty Index is based on the following relationship: 


$$
I_{H P}=\frac{\frac{1}{n} \sum_{i=1}^{n} e_{h}-\frac{1}{n} \sum_{i=1}^{n} e_{h \_r i s k}}{\frac{1}{n} \sum_{i=1}^{n} i_{\text {risk }}}
$$

where $e_{h}$ is the expenditure of all households on healthcare, $e_{h_{-} \text {risk }}$ is healthcare expenditure in income risk groups of households and $i_{\text {risk }}$ is income in risk households.

Results. The issue of healthcare expenditure is closely connected with total income and household expenditure monitored for individual categories according to the COICOP classification. In the monitored period, the amount of net cash household income and the amount of net household expenditure is shown in Figure 1. The values attained show that the living standard of Czech households is increasing, above all their economic component. The difference is increasing between attained income and realised expenditure to satisfy their needs, households have a surplus of cash. The share of expenditure on income has changed from $95.5 \%$ in 2007 to $77 \%$ in 2016 (Table 2). Moreover the year 2016 does not yet include the significant increase in average wages and pensions which came about in the last two years.

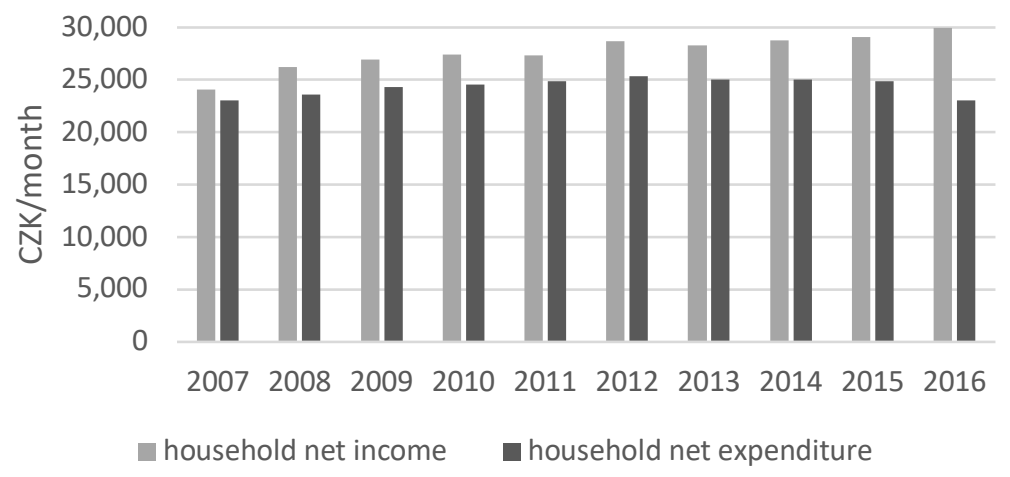

Source: HBS.

Figure 1. Average household net cash income and expenditure

Table 2. Share of expenditure in household income in years 2007 to 2016

\begin{tabular}{|c|c|c|c|}
\hline Year & Share of expenditure in income & Year & Share of expenditure on income \\
\hline 2007 & $95.54 \%$ & 2012 & $88.33 \%$ \\
\hline 2008 & $90.15 \%$ & 2013 & $88.56 \%$ \\
\hline 2009 & $90.32 \%$ & 2014 & $87.20 \%$ \\
\hline 2010 & $89.40 \%$ & 2015 & $85.36 \%$ \\
\hline 2011 & $91.13 \%$ & 2016 & $77.11 \%$ \\
\hline
\end{tabular}

Source: HBS.

For the gradual fulfilment of the objectives of the article on the availability of healthcare to the public, public expenditure on healthcare and its individual components, i.e. healthcare expenditure provided by government institutions and contributions of health insurance companies, also needs to be known in view of the nature of the state (Table 3). 
Table 3. Public healthcare expenditure in the Czech Republic according to sources

\begin{tabular}{|c|c|c|c|c|}
\hline \multicolumn{5}{|c|}{ of financing in CZK } \\
\hline & 2007 & 2010 & 2014 & 2016 \\
\hline Total public sources & 206565 & 282166 & 291572 & 300210 \\
\hline $\begin{array}{l}\text { Thereof public health } \\
\text { insurance }\end{array}$ & 183713 & 231889 & 234602 & 237700 \\
\hline Thereof state budget & 14199 & 45187 & 50721 & 55895 \\
\hline $\begin{array}{l}\text { Thereof regional and } \\
\text { municipal budgets }\end{array}$ & 8653 & 5091 & 6250 & 6614 \\
\hline Total private sources & 3879 & 9217 & 10668 & 10222 \\
\hline $\begin{array}{l}\text { Direct household } \\
\text { payments }\end{array}$ & 31491 & 42705 & 46490 & 51215 \\
\hline $\begin{array}{c}\text { Total healthcare } \\
\text { expenditure }\end{array}$ & 241935 & 334088 & 348730 & 361647 \\
\hline
\end{tabular}

Source: CZSO, 2010 and CZSO, 2019.

Healthcare expenditure (Table 3) in the monitored years 2007-2016 increased by about $49 \%$ and total public resources increased by $45 \%$. Public resources are a high share consisting of public health insurance (in 2007 this share reached $88.9 \%$, in 2016 it fell to $79.1 \%$ ). State budget resources increased four fold and their share of public resources ranges between $6.8 \%$ in 2007 and $18.6 \%$ in 2016. Regional and municipal resources saw a fall in funds. A low share of financial resources from the budget is seen above all in research and education and it is also apparent from the structure of expenditure. The biggest share of expenditure (Table 4) consists of hospital services (40-42\%) and in the course of the monitored years has almost not changed, ambulatory services (19-21\%) and public healthcare services (16-19\%). The share spent on medical instruments and equipment in 2007 reached $15.6 \%$ and since that year has constantly decreased, in the years of economic growth it recorded the lowest value (11.5\%). So investment in healthcare is not increasing and this can be seen in the following years in the quality of healthcare. Expenditure is also falling in public services and administrative support of activity in healthcare. Research and development in healthcare is totally inadequate in its share of $0.32 \%$ and does not enable innovation in healthcare. Its increase by two fold in the last two years of monitoring is still inadequate for maintaining the standard of healthcare in the period of sharp innovative development.

Table 4. Structure of healthcare expenditure

\begin{tabular}{|c|c|c|c|c|}
\hline & $\mathbf{2 0 0 7}$ & $\mathbf{2 0 1 0}$ & $\mathbf{2 0 1 4}$ & $\mathbf{2 0 1 6}$ \\
\hline Medical products and instruments & $15.63 \%$ & $14.07 \%$ & $13.09 \%$ & $11.46 \%$ \\
\hline Ambulatory services & $20.26 \%$ & $21.72 \%$ & $21.65 \%$ & $19.64 \%$ \\
\hline Hospital services & $40.76 \%$ & $42.03 \%$ & $42.90 \%$ & $40.85 \%$ \\
\hline Public healthcare services & $19.93 \%$ & $18.27 \%$ & $18.86 \%$ & $16.63 \%$ \\
\hline Research and development in healthcare & $0.32 \%$ & $0.31 \%$ & $0.67 \%$ & $0.60 \%$ \\
\hline Administrative support & $3.10 \%$ & $3.59 \%$ & $2.82 \%$ & $2.57 \%$ \\
\hline
\end{tabular}

Source: Eurostat, 2019.

In Tables 3 and 4 the values show that any change in the economic development of society is displayed in expenditure from public resources. The economic recession in 2010 may not have seen a fall in absolute values in healthcare expenditure from public resources, but it recorded only a $6.1 \%$ increase 
between 2010 and 2016. It was seen above all in research and development in healthcare and instruments and equipment.

It could be assumed that just as lack of funds could be seen in healthcare expenditure in the country so it can be seen in households. The expenditure listed in Figure 2 and 3 provides somewhat different facts.

Healthcare expenditure of households as a whole increased from 2007 to 2016 by an absolute value of CZK 140 per month, i.e. by about $32 \%$. The years 2007 to 2010 saw an increase, in further monitored years right up to 2016 it remained at around the same level. Figure 2 confirms the expectations that the poorest households spend the least money on their healthcare in comparison with richer households. Healthcare expenditure provided by households in 2010 was higher in all deciles as compared to 2007, i.e. even by low-income households. The increase of healthcare expenditure in all income deciles shows the need to implement this expenditure due to the objective necessity and at the price of making savings on other expenditure. This is confirmed by the known fact that the consequences of the economic recession are displayed on household income and on expenditure and the living standard of the population with a certain time shift. But the increase in healthcare expenditure is different in the individual income deciles. We can gain a more detailed view by monitoring the expenditure by groups created according to the income deciles 1-10. The highest expenditure increase was reached in deciles 6-10 (with the exception of 7), i.e. households with the highest income. A surprise is the stagnation of healthcare expenditure in the next monitored years (right up to 2016, as the last year monitored), which can be explained not only by the need, but also the possibility of satisfying this need. In some income groups (in 2, 3, 4 and 8) there was a fall during the course of the years in absolute value for healthcare expenditure. The low healthcare expenditure in the first decile should arouse interest.

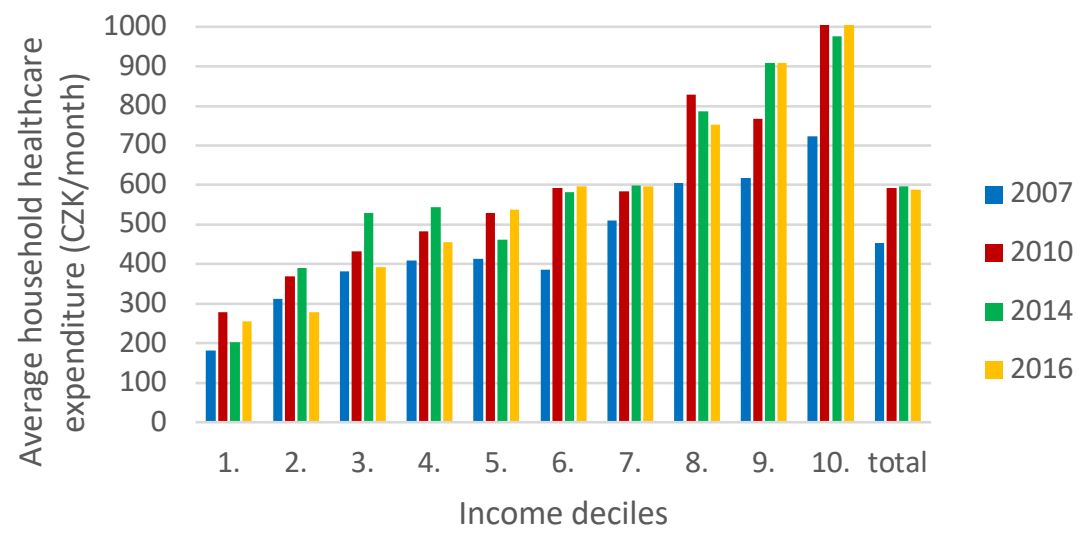

Source: HBS

Figure 2. Average household expenditure according to income deciles

The same data on household healthcare expenditure expressed relatively to their income (Figure 3) show the fact that low-income households spend more than others from their income. If we look at the situation according to the deciles, we see that the trend is according to a theoretical assumption. This trend is confirmed only from the second decile when the relative share of healthcare expenditure in its income falls slightly in individual years, but with slight variability. However the trend in years shows slight differences between the income deciles. The first income decile above all shows a different trend. In 2016 
the relative share of expenditure reached the highest value ever. This confirms the necessity and priority of these expenditures in contrast to all others. During the monitored years the share of healthcare expenditure behaves somewhat differently. In most income deciles there was an increase in contrast to 2007, but in 2014 there is already the anticipated fall - in view of the income increase. The relative expression of healthcare expenditure confirms that low-income households spend the most from their income of between 2-3.3 \% of their income, other households between 1.5-2.2\%.

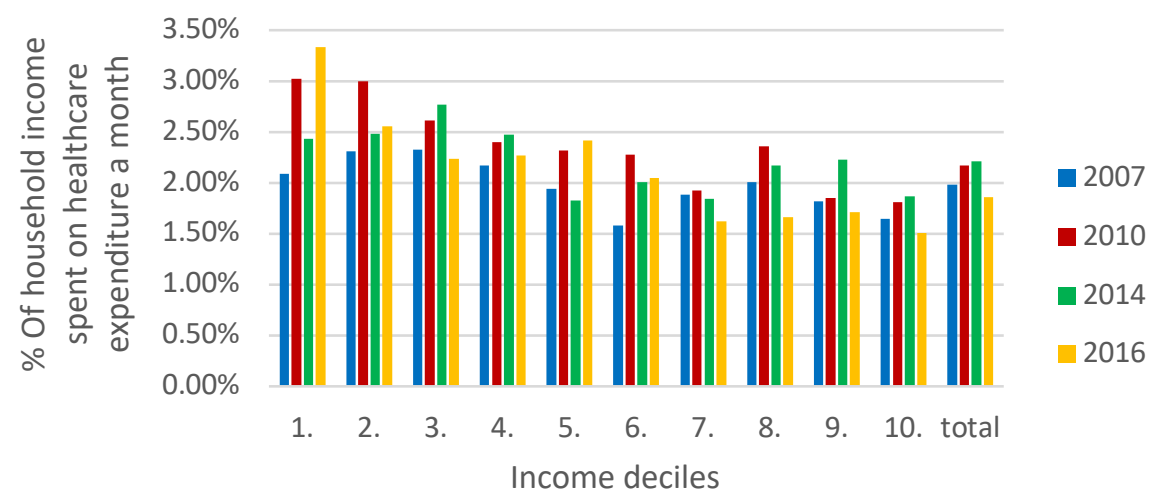

Figure 3. Share of healthcare expenditure in household income according to income deciles Source: HBS.

The household income situation classified according to individual deciles provided a better picture of the lack of household funds, but equally important are the findings of which households the deciles are made up. The structure of the individual income deciles according to the items of economic activity is in Table 5. This table shows that the first income decile consists of about three quarters of pensioners. In the next deciles with increasing income the share of pensioners decreases in the given decile. The representation of the individual groups, above all pensioners and the unemployed is crucial for forming proposals of remedial measures in social policy.

Table 5. Decile classification of households according to economic activity in $\mathbf{2 0 1 6}$

\begin{tabular}{|c|c|c|c|c|c|c|c|c|c|c|}
\hline & Decile 1 & Decile 2 & Decile 3 & Decile 4 & Decile 5 & Decile 6 & Decile 7 & Decile 8 & Decile 9 & Decile 10 \\
\hline $\begin{array}{c}\text { Old age } \\
\text { pensioners }\end{array}$ & $72.15 \%$ & $68.35 \%$ & $34.18 \%$ & $51.90 \%$ & $56.96 \%$ & $27.22 \%$ & $16.46 \%$ & $7.59 \%$ & $7.59 \%$ & $7.59 \%$ \\
\hline Employees & $5.70 \%$ & $15.19 \%$ & $44.30 \%$ & $36.08 \%$ & $32.28 \%$ & $50.00 \%$ & $67.72 \%$ & $76.58 \%$ & $68.35 \%$ & $77.85 \%$ \\
\hline $\begin{array}{c}\text { Self- } \\
\text { employed }\end{array}$ & $5.06 \%$ & $6.33 \%$ & $12.66 \%$ & $9.49 \%$ & $9.49 \%$ & $15.82 \%$ & $13.92 \%$ & $15.19 \%$ & $22.78 \%$ & $13.92 \%$ \\
\hline Unemployed & $13.29 \%$ & $8.23 \%$ & $8.23 \%$ & $2.53 \%$ & $0.63 \%$ & $6.96 \%$ & $1.90 \%$ & $0.63 \%$ & $1.27 \%$ & $0.63 \%$ \\
\hline Students & $3.80 \%$ & $1.90 \%$ & $0.63 \%$ & $0.00 \%$ & $0.63 \%$ & $0.00 \%$ & $0.00 \%$ & $0.00 \%$ & $0.00 \%$ & $0.00 \%$ \\
\hline
\end{tabular}

Source: HBS.

Individual deciles as income categories do not take into account further factors affecting the position of the individual and above all his behaviour in connection with healthcare, so Figure 4 shows that household healthcare payments differ between households depending on socio-economic household category of households. 


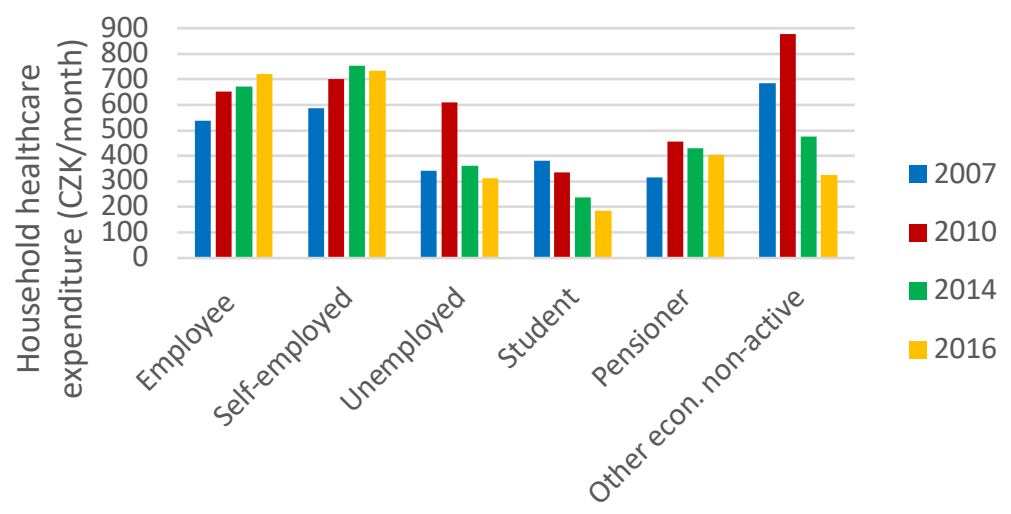

Figure 4. Average monthly healthcare expenditure depending on the pertinence of the person Source: HBS. at the head of the socio-economic category

Figure 4 shows that two of the biggest groups (employees and self-employed) spend increasingly more on their healthcare during the monitored years. Their income situation is stabilised, and income during the period of economic growth rises, so healthcare expenditure rises too (in what expenditure categories is stated further). The absolute amount of expenditure for both of the biggest groups is almost identical throughout the period. When arranging the groups according to the amount of healthcare expenditure the pensioner group comes next, in the absolute amount of expenditure it ranges at about $60 \%$ of expenditure of the previous two groups. It comes very close to the amount of expenditure of the unemployed group. In this group it is interesting that in 2010, i.e. at the time of the recession, this group spent the most on healthcare during all the monitored years. It points to the need for this expenditure. In the student group expenditure has been falling since 2007. As a reason it must be realised that the data applies to households and in this group this mostly concerns single-member households, young, mostly without systematic healthcare. The group of other economically active people is so variable in its structure that does not enable generalisation. Figure 5 shows what items and at what amount are spent by households on healthcare according to individual categories.

Figure 5 shows that most people pay for non-prescription drugs followed by prescription drugs, orthopaedic and therapeutic aids, ambulatory dental care, ambulatory medical care, institutional healthcare, ambulatory care provided by middle healthcare staff and other medical products. Its sequence changes if we consider expenditure during the course of time. Expenditure falls significantly for prescription drugs, expenditure for ambulatory dental care and for non-prescription drugs increases significantly.

The amounts spent monthly by households for individual healthcare expenditure categories are shown in the diagrams in Figure 6 and 7 . Because the authors were interested in determining whether all types of households with different income or social group, could afford to pay for healthcare needs, Figure 6 and 7 offer a comparison of healthcare expenditure in all Czech households and senior households. These are households where the head of the household is a senior citizen. There is a significant difference between expenditure of households in the Czech Republic and expenditure of senior households. Households present their total expenditure in hundreds or tens of crowns a month, pensioner households in tens or units of CZK. Different values on the $Y$ axis need to be considered for their comparison (Figure 6 and 7). 


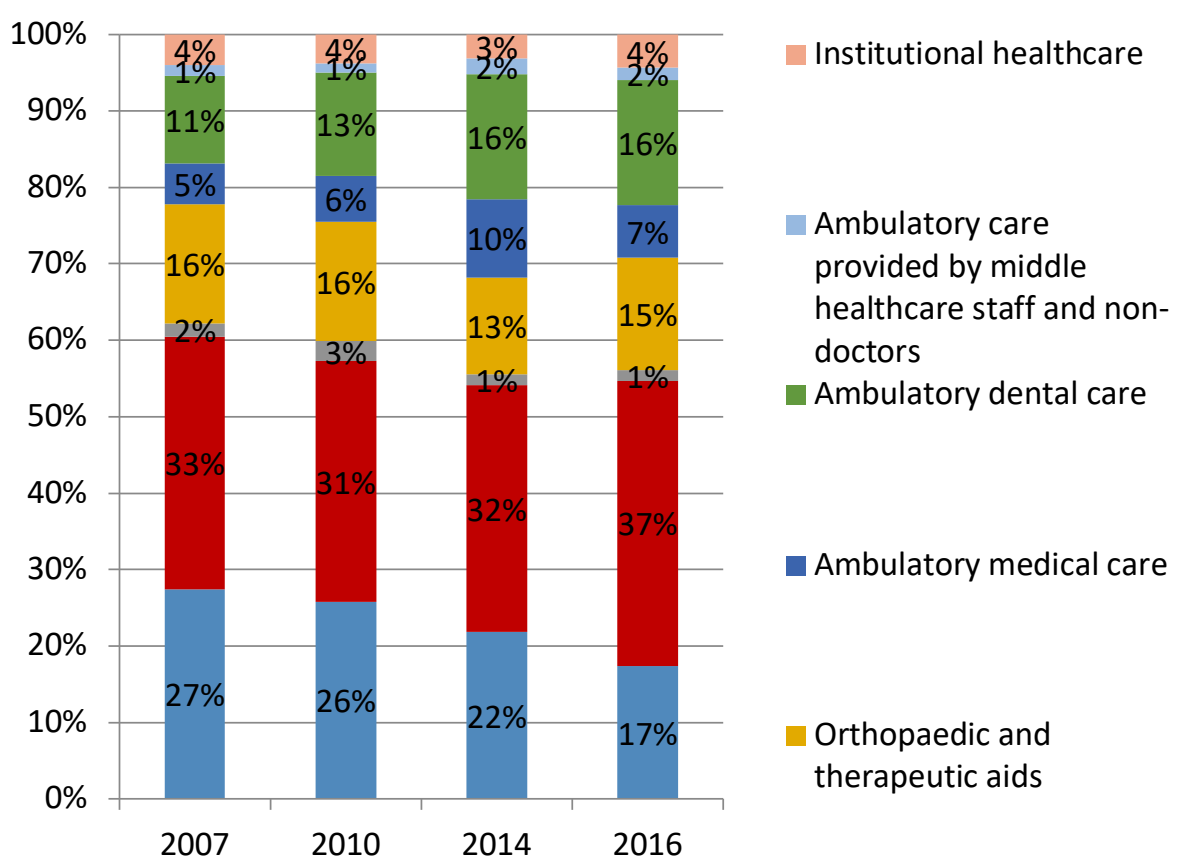

Figure 5. Structure of household healthcare expenditure according to expenditure categories Source: HBS.

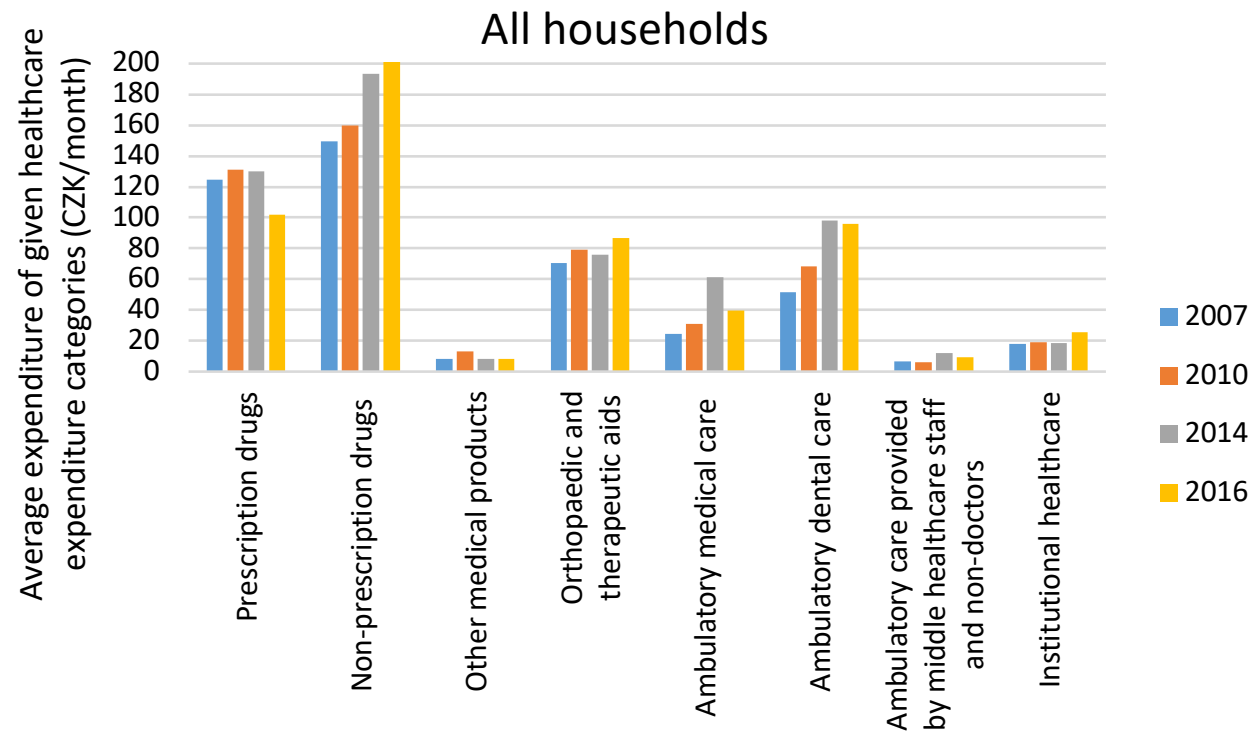
Source: HBS.

Figure 6. Household expenditure according to the healthcare category 


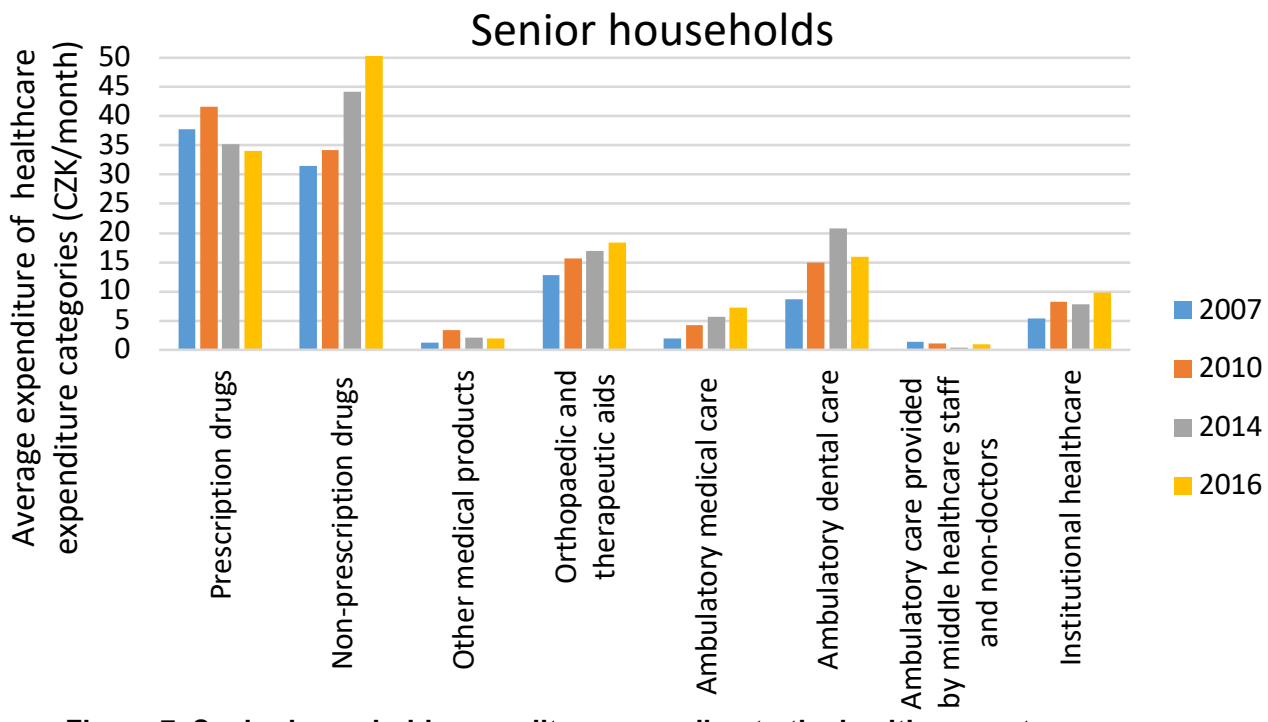
Source: HBS.

Figure 7. Senior household expenditure according to the healthcare category

A comparison of the files of households in total and senior households in total expenditure is at a ratio of 4:1. A comparison according to individual expenditure categories show that pensioner households approaches households in the prescription drug category, but does not approach categories where a decision may be made about the quality of care (dental ambulatory care, orthopaedic and therapeutic aids). The category of expenditure for non-prescription drugs of the nature of preventive care in recent years of monitoring saw a positive trend, i.e. even pensioner households can afford them.

The subjective opinions of households as they regard their ability to pay for healthcare are the subject of the EU-SILC survey in 2016 on the income situation and household living conditions. The results of this survey are found in Table 6 .

Table 6. Ability to pay of households for healthcare in 2016

\begin{tabular}{|l|c|c|c|}
\hline & All households & Senior households & 1st income decile \\
\hline With great problems & $2.90 \%$ & $3.56 \%$ & $7.76 \%$ \\
\hline With problems & $28.98 \%$ & $37.73 \%$ & $37.14 \%$ \\
\hline Easy & $31.55 \%$ & $25.74 \%$ & $16,35 \%$ \\
\hline Very easy & $3.96 \%$ & $1.81 \%$ & $1.55 \%$ \\
\hline No healthcare expenditure & $32.61 \%$ & $31.15 \%$ & $37.20 \%$ \\
\hline
\end{tabular}

Source: EU-SILC.

One third of Czech households have difficulty paying for healthcare, thereof $3 \%$ with great problems. In seniors this is $41 \%$ of households and the biggest percent of households ( $47.5 \%$ ) are households of the 1 st income decile that have difficulty covering their healthcare expenditure and $7.8 \%$ of them with great difficulty. Testing of the cogency of the differences in perceiving the ability to cover healthcare expenditure using the Chi-squared test shows a difference between the group of households in total, the group of the 1 st income decile and the group of seniors always with the p-value of 0.000 . Based on Table 
6 the group of seniors can be perceived as less of a problem in covering healthcare expenditure. It is also worth noticing that a third of households have no healthcare expenditure. This is also due to the fact that many households have not used expenditure in the given year, the increased percentage in the group of the 1st income decile may mean that households cannot afford healthcare or do not want to spend money on healthcare.

Households in the first income decile with insufficient income cannot afford expenses in various areas of consumption at the required amount to satisfy their living conditions which is also seen in the area of healthcare. The Health Poverty Index (Table 7) revealed that households in the first decile would need their income to be higher by at least $4.36 \%$ to be able to afford average healthcare expenditure and so they do not have to be restricted and buy pharmaceuticals and healthcare services at such a level as the average consumer in society. In absolute numbers a low-income household from the first income decile would need their income to be CZK 333 higher a month. The situation in the group of senior households is not that serious. They would need their income to be $0.91 \%$ higher to be able to afford average healthcare expenditure.

Table 7. Health Poverty Index

\begin{tabular}{|c|c|c|c|}
\hline & All households & 1st income decile & Senior households \\
\hline $\begin{array}{c}\text { Average monthly household } \\
\text { healthcare expenditure (CZK) }\end{array}$ & 588 & 255 & 404 \\
\hline $\begin{array}{c}\text { Average monthly household } \\
\text { income (CZK) }\end{array}$ & 31620 & 7645 & 20287 \\
\hline $\begin{array}{c}\text { Household deficit to average } \\
\text { expenditure (CZK) }\end{array}$ & - & 333 & 184 \\
\hline Health Poverty Index & - & $\mathbf{4 . 3 6} \%$ & $\mathbf{0 . 9 1 \%}$ \\
\hline
\end{tabular}

Source: HBS and own calculation.

Discussion. The increase of public healthcare expenditure in years $2007-2016$ about $40 \%$ is due to contributions of health insurance companies, expenditure of departments and territorial organisations is stagnating. The share spent on medical devices and equipment in 2007 reached $15.6 \%$ and is decreasing from this year. The year of economic growth say the lowest value $(11.5 \%)$. The increase of public healthcare expenditure indicates an appropriate state health policy that support public health. But the problem appears in health care investments that do not increase. Investments are very low and quality of healthcare will probably decrease in future.

From 2007 to 2016 healthcare expenditure of households as a whole increased in absolute value by CZK 140 a month, i. e. approx. by 32\%. This increase is not equal during the years, the years 2014-2016 saw stagnation. Expectations were confirmed that the poorest households spend less money on healthcare as compared to wealthier households. We are in accordance with previous studies (Wang et al., 2016; Mtei et al., 2015; Lenhart, 2019) that healthcare expenditure is depended on household income situation.

Given the arrangement of healthcare expenditure according to income deciles we state the trend according to a theoretical assumption. This trend is confirmed, but only from the second income decile when the relative difference of healthcare expenditure to its income falls slightly, but with slight variability in individual years. The relative number of healthcare expenditure confirms that low-income households spend the most of their income on healthcare of between $2-3.3 \%$ of their income, other households between $1.5-2.2 \%$. In terms of the ratio between household healthcare income and expenditure the necessary attention is confirmed to the first income decile. Our results confirm the explanation by Knaul 
et al. (2012) that low-income households must pay more from their income for health and sometimes they are not able to afford required medicines or healthcare services.

The income situation of employees and self-employed is stabilised, income at the time of economic growth rises so healthcare expenditure also rises. That is probably why they spend the most on their healthcare. In the absolute amount of expenditure both groups are almost identical throughout the period. When arranging the groups according to the amount of healthcare expenditure this is followed by the pensioner group, in the absolute amount of expenditure it is about $60 \%$ of the expenditure of the previous two groups. They are very close to the amount of expenditure of the unemployed group. This fact that expenditures of pensioners are lower than expenditures of employees and self-employed indicates a problem because also Fukawa (2017) says that elderly need to use hospital services more frequently and need more medicines. However, expenditures of pensioner are lower so it is probably caused by their inability to afford required healthcare. In the unemployed group, just as in the economically inactive group and in view of the type of commodity which is the subject of our interest, it is logical that in 2010, i.e. at the time of the recession, these groups spent the most in absolute value on healthcare during all the monitored years. It is a reflection of necessity and irreplaceability in satisfying healthcare needs.

The results of the SILC survey in 2016, a part of which were findings of how households regard their ability to pay for their healthcare expenditure, showed that about one third of Czech households has difficulty covering their healthcare expenditure, thereof $3 \%$ with great difficulty, for seniors this is $41 \%$ of households, thereof $3.5 \%$ with great difficulty and the greatest problem are households of the first decile, which cover their healthcare expenditure with difficulty in $45 \%$ and of them $7.8 \%$ with great difficulty. It is worth noting that a third of households do not have healthcare expenditure for whatever reasons. This confirmed the indication that low-income households don't have enough money to afford required healthcare. This finding matches with Chaupain-Guillot and Guillot (2015).

The health poverty index was constructed after performed analyses. From the value of this index it was re-confirmed that the worst situation in covering healthcare expenditure is in the first income decile $(4.36 \%)$ and with a sufficient gap followed by the pensioner group ( $0.91 \%)$. The index shows that lowincome households in the first decile would need their income to be higher by at least $4.36 \%(0.91 \%$ for pensioners) to be able to afford average healthcare expenditure and so they do not have to be restricted and buy pharmaceuticals and healthcare services.

Conclusions. Public healthcare expenditure in the monitored years of 2007-2016 increased. However, investment in healthcare is not increasing and this is shown in the quality of medical care in the following years. The trend of household healthcare expenditure shows slight difference between income deciles. Low-income households spend the most of their income on healthcare (3.3\% of their income) in comparison with other households ( $2.2 \%$ of their income). In 2016 this low-income decile reached the highest value of the share of healthcare expenditure in income. This is confirmed by the necessity and priority of further analyses in terms of the structure of this decile and the problems facing households. Low-income households probably cannot afford required healthcare.

Employees and self-employed spend the most on their healthcare in households according to socioeconomic classes. The unemployed group and pensioners pay less for healthcare than previous two groups. This also indicate a problem because pensioners need healthcare more than healthy young people in active age. Pensioners cannot afford appropriate healthcare.

The biggest part of expenditure according to the individual categories of expenditure is made up of non-prescription drugs, followed by prescription drugs, orthopaedic and therapeutic aid expenditure, ambulatory dental care, ambulatory medical care, institutional healthcare, ambulatory care provided by middle healthcare staff middle healthcare staff and other healthcare products. This order does not change if we consider expenditure for the individual categories over the course of time. There is a significant fall 
in prescription drug expenditure, a significant rise in ambulatory dental care expenditure and nonprescription drug expenditure.

The results of the SILC survey confirmed that low-income households face problems with payments for their healthcare. Even other households face these problems - one third of all households, and almost half of senior households.

The contribution of this article, based on the conducted analyses, is the creation of the health poverty index, which in one number expresses \% increase of its income to reach the value of average healthcare expenditure and so it is not detrimental to not satisfying other needs. The index revealed that pensioner household need to have their income at least for $4.36 \%$ higher to achieve average healthcare standard ( $0.91 \%$ higher for seniors). The indicator can be used for prepared socio-legal measures. The conducted analyses and their results show the need for qualitative research to discover the reasons why medical care is used only at basic level with the lowest expenditure. Further research needs to focus above all on the first income decile as the most at risk in satisfying healthcare needs. This necessity is enhanced by the analysis of the distribution of the senior group into income deciles. The first income decile consists of $72.15 \%$ pensioners.

Author Contributions: Conceptualization, I. A., N. H. and J. S.; methodology, I. A., N. H. and J. S.; software, I. A., N. H.; validation, J. S and I. A.; formal analysis, I. A., N. H. and J. S.; investigation, I. A., $\mathrm{NH}$. and J. S.; resources, I. A. and J. S.; data curation, I. A. and J. S.; writing-original draft preparation, I. A., N. H.; writing-review and editing, J. S..; visualization, I. A.; project administration, I. A. and N. H.

Funding: This research was funded by: Research Infrastructure for Young Scientists, grant number CZ.02.1.01/0.0/0.0/16_017/0002334; Minister of Science and Higher Education titled "Regional Initiative of Excellence" in 2019-2022, project number 018/RID/2018/19, the amount of funding PLN 10788423,16

\section{References}

Adda, J., Banks, J., Gaudecker, H. M. (2009). The impact of income shocks on health: Evidence from cohort data, Journal of the European Economic Association, 7(6): 1361-1399. doi: 10.1162/JEEA.2009.7.6.1361.

Atanasova, E., Pavlova M., Groot, W. (2015). Out-of-Pocket Patient Payments for Public Health Care Services in Bulgaria, Front Public Health, 3(175). doi: 10.3389/fpubh.2015.00175.

Atkinson, A. B., Cantillon, B., Marlier, E., Nolan, B. (2007). The EU and Social Inclusion. Bristol: Policy Press, The University of Bristol.

Bradbury, B., Jenkins S. P., Micklewright, J. (2001). The Dynamics of Child Poverty in Industrialised Countries. Cambridge: Cambridge University Press a UNICEF.

Callander, E. J., Fox, H., Lindsay, D. (2019). Out-of-pocket healthcare expenditure in Australia: trends, inequalities and the impact on household living standards in a high-income country with a universal health care system, Health Economics Review, 9(1): 1-8. doi: 10.1186/s13561-019-0227-9.

Cazacu, L., Oprescu, A. E. (2015). Healthcare Marketing - A Relational Approach, Revista Economica, 67(5): 59-72.

Chaupain-Guillot, S., Guillot, O. (2015). Health system characteristics and unmet care needs in Europe: an analysis based on EU-SILC data, The European Journal of Health Economics, 16(7): 781-796. doi: 10.1007/s10198-014-0629-x.

CZSO1. (2019). Household Budget Survey (HBS) - Methodology, available at: https://www.czso.cz/csu/czso/household-budgetsurvey-hbs-methodology

CZSO2. (2010). Vysledky zdravotnickych uctu CR 2000-2008, available at: https://www.czso.cz/documents/10180/20554883/ 330610a2.pdf/5a262f0f-2887-496c-b869-c60479c02ccf?version=1.0

CZSO $^{3}$. (2019). Vysledky zdravotnickych uctu CR 2010-2017, available at: https://www.czso.cz/documents/10180/90577099/ 26000519k2.pdf/a9bfc998-7946-499b-b61e-5d0b0b985963?version=1.0

European Commission. (2019). Public Health: Health Indicators, available at: https:ec.europa.eu/health/indicators/policy_en Eurostat ${ }^{1}$. (2019). Glossary: COICOP HICP, available at: https://ec.europa.eu/eurostat/statistics-explained/index.php/ Glossary:COICOP_HICP

Eurostat ${ }^{2}$. (2019). General government expenditure by function (COFOG), available at: http://appsso.eurostat.ec.europa.eu/nui/ show.do?dataset=gov_10a_exp\&lang=en 
Fukawa, T. (2017). Elderly Population Projection and Their Health Expenditure Prospects in Japan, Modern Economy, 8(11): 1258-1271. doi: 10.4236/me.2017.811085

Gadowska, D., Rozycka, A. (2016). Innovations, R\&D and Knowledge Transfer in the Healthcare Sector, Forum Scientiae Oeconomia, 4(3): 27-54

Giammanco, M. D., Gitto, L. (2019). Health expenditure and FDI in Europe, Economic Analysis and Policy, 62: 255-267. doi: 10.1016/j.eap.2019.04.001.

Globerman, S., Shapiro, D. (2002). Global foreign direct investment flows: The role of governance infrastructure, World Dev., 30(11): 1899-1919. doi: 10.1016/S0305-750X(02)00110-9.

Guio, A. C., Museux, J. M. (2006). The Situation of Children in the EU: Comparison between Income Poverty and Material Deprivation Approaches. Paper Prepared for the 29th General Conference of The International Association for Research in Income and wealth. Joensuu (Finland) August 20-26.

Kavosi, Z., Rashidian, A., Pourreza, A., Majdzdadeh, R., Pourmalek, F., Hosseinpour, A., Mohammad, K., Arab, M. (2012). Inequality in household catastrophic health care expenditure in a low-income society of Iran, Health Policy \& Planning, 27(7): 613623. doi: $10.1007 / \mathrm{s} 10754-018-9253-0$.

Kemp, A., Preen, D., Glover, J., Semmens, J., Roughead, E. (2013). Impact of cost of medicines for chronic conditions on low income households in Australia, Journal of Health Services Research \& Policy, 18(1): 21-27. doi: 10.1258/jhsrp.2012.011184.

Khan, M. A., UI Husnain, M. I. (2019). Is health care a luxury or necessity good? Evidence from Asian countries, International Journal of Health Economics and Management, 19(2): 213-233. doi: 10.1007/s10754-018-9253-0.

Knaul, F. M., Wong, R., Arreola-Ornelas, H. (2012). Financing Health in Latin America: Household Spending and Impoverishment, United States of America: Harvard Global Equity Initiative.

Lenhart, O. (2019). The effects of income on health: new evidence from the Earned Income Tax Credit, Review of Economics of the Household, 17(2): 377-410. doi: 10.1007/s11150-018-9429-x.

Liu, X., Wong, H., Liu, K. (2016). Outcome-based health equity across different social health insurance schemes for the elderly in China, BMC Health Services Research, 1-12. doi: 10.1186/s12913-016-1261-5.

Metys, K. A., Balog, P. (2006). Marketing ve farmacii, Praha: Grada.

Mokrysz, S. (2016). Consumer Preferences and Behaviour on the Coffee Market in Poland. Forum Scientiae Oeconomia, 4(4) 91-107.

Mtei, G., Borghi, J., Hanson, K. (2015). Predicting Consumption Expenditure for the Analysis of Health Care Financing Equity in Low Income Countries: A Comparison of Approaches, Social Indicators Research, 124(2): 339-355. doi: 10.1007/s11205-0140796-2.

OECD. (2019), Who we are, available at: https://www.oecd.org/about/

Olecich.cz. (2017). Dostupnost leciv v Ceske republice, available at: http://www.olecich.cz/encyklopedie/dostupnost-leciv-v-cr

Pascual-Saez, M., Cantarero-Prieto, D., Castaneda, D. (2017). Public health expenditure, GDP and the elderly population: a comparative study, International Journal of Social Economics, 44(10): 1390-1400. doi: 10.1108/IJSE-03-2016-0106.

Peacock, D., Devlin, N., Mcgee, R. (1999). The horizontal equity of health care in New Zealand, Australian and New Zealand Journal of Public Health, 23(2): 126-130.

Radulescu, V., Cetina, l., Orzan, G. (2012). Key Factors that Influence Behavior of Health Care Consumer, the Basis of Health Care Strategies, Contemporary Readings in Law, 4(2): 992-1001.

Rittakalio, V. M., Bradshaw, J. (2005). Child Poverty in the EU, Nordic Research, Council Project.

Rodriguez, A. F., Nieves Valdez, M. (2019). Health care expenditures and GDP in Latin American and OECD countries: a comparison using a panel cointegration approach, International Journal of Health Economics and Management, 19(2): 115-153. doi: 10.1007/s10754-018-9250-3.

Statistika\&My. (2013). Vydaje domacnosti na zdravotni peci. Available at: http://www.statistikaamy.cz/2015/03/vydajedomacnosti-na-zdravotni-pecil

Thomas, R. K. (2005). Marketing Health Services, Chicago: Health Administration Press.

Wang, L., Wang, A., Zhou, D., Fitzgerald, G., Ye, D., Jiang, Q. (2016). An Empirical Analysis of Rural-Urban Differences in OutOf-Pocket Health Expenditures in a Low-Income Society of China, PLoS ONE, 11(5): 1-12. doi: 10.1371/journal.pone.0154563 WHO. (2019). Health Impact Assessment (HIA): The determinants of health, available at http://www.who.int/hia/evidence/doh/en/

Yao, W., Gao, D., Sheng, P. (2019). The impact of education on healthcare expenditure in China: quantity or quality, Applied Economics Letters, 26(14): 1192-1195. doi: 10.1080/13504851.2018.1542118.

Zamazalova, M. (2009). Marketing obchodni firmy. Praha: Grada Publishing 
Ірена Антосова, Університет Менделя в Брно (Чеська Республіка);

Над'я Хазучова, Ph.D., Університет Менделя в Брно (Чеська Республіка);

Яна Ставкова, CSc., професор, Університет Менделя в Брно (Чеська Республіка).

Сегментація ринку медичних послуг

Головною метою статті $\epsilon$ аналіз доступності медичних послуг для різних груп населення залежно від рівня їх доходу. Аналіз наукової літератури з означеної тематики дослідження дозволив зробити висновок, що значний відсоток суспільства стикається з проблемою доступу до медичних послуг через низький рівень їх доходів. У статті авторами оцінено державні витрати на медичне обслуговування суспільства. Визначено, що питома вага витрат на наукові дослідження у галузі охорони здоров'я є надзвичайно низькою. Таким чином, актуальність даної статті полягає у необхідності дослідження ринку медичних послуг, доступності медичного обслуговування та ліків для суспільства. У рамках статті виокремлено та проаналізовано сегменти малозабезпечених сімей із недостатнім рівнем медичного обслуговування. Емпіричну базу дослідження склали панельні дані сформовані на основі аналізу сімейного бюджету та статистичних даних Європейського союзу за 2007, 2010, 2014 та 2016 роки у Чеській республіці. Отримані результати дослідження свідчать про те, що перший низько-дохідний дециль мав найнижчі витрати на медичне обслуговування у абсолютному вираженні. Однак, питома вага витрат на медичне обслуговування сімей із низьким рівнем доходу $є$ найвищою порівняно із іншими сім'ями. Авторами зазначено, що до першого децилю доходів увійшли пенсіонери за вислугою років та безробітні. Результати аналізу структури витрат на медичне обслуговування (відповідно до категорій витрат) свідчать про те, що сформована вибірка споживачів витрачає найбільшу частку бюджету на придбання ліків без рецепту лікаря, менше на ліки з рецептом лікаря, ортопедичне та терапевтичне обладнання, амбулаторну стоматологічну допомогу та амбулаторне лікування. Таким чином, отримані результати дослідження дають підстави стверджувати, що певні групи сімей не можуть собі дозволити відповідне медичне обслуговування. При цьому згідно індексу бідності встановлено, що сім'ї із низьким рівнем доходу потребують підвищення ї рівня доходу щонайменше на 4,36\% для того, щоб мати змогу забезпечити собі належне медичне обслуговування.

Ключові слова: поведінка споживача, здоров'я, група здоров'я, витрати на медичне обслуговування, стан доходів.

Manuscript received: 28.07.2019

(C) The author(s) 2019. This article is published with open access at Sumy State University. 